\title{
The localization of vanadium- and nitrate-sensitive ATPases in Cucumis sativus $\mathbf{L}$. root cells
}

\author{
GRAZYNA KLOBUS
}

Department of Plant Physiology, Institute of Botany, Wrockaw University, Kanonia 6/8, 50-328 Wroclaw, Poland

(Received: January 27, 1987. Accepted: March 25, 1987)

\begin{abstract}
Distinct separation of plasma membrane and tonoplast membranes was attained by centrifugation of cucumber root microsomes in a sucrose density gradient. The fractions enriched in plasma membranes, identified on the basis of the sensitivity of ATPases to $\mathrm{VO}_{4}^{3-}$, sedimented at a specific density of $1.1463-1.1513 \mathrm{~g} \times \mathrm{cm}^{-3}$. They did not exhibit cytochrome oxidase activity and there was only trace activity of the azide-sensitive ATPase in these fractions. The fractions enriched in tonoplast membranes, having peak activity of nitrate-sensitive ATPase, were found in the region of specific densities of 1.1082-1.1175. The presence of vanadium-sensitive and azide-sensitive ATPases was not found in these fractions. The ATPase inhibitors, DCCD, DES and EDAC, inhibited the activity of both vanadium-sensitive and nitrate-sensitive ATPases.
\end{abstract}

Key words: Cucumis sativus, ATPases, plasma membrane, tonoplast

\section{INTRODUCTION}

Recent studies (S ze 1984) have shown that one of the basic criteria making it possible to distinguish among the membrane-associated ATPases in plant cells is their sensitivity to anions such as $\mathrm{VO}_{4}^{3-}, \mathrm{NO}_{3}^{-}$and $\mathrm{N}_{3}^{-}$. The plasma membrane-associated ATPase is not not sensitive to $\mathrm{NO}^{-3}$ and is specifically inhibited by ortho-vanadate (Bowman et al. 1979, Gallagher and Leonard 1982, O'Neill et al. 1983, Lew and Spanswick 1984, Buczek and Sulej 1986), while the tonoplast-associated ATPase is not sensitive to or- 
tho-vanadate, showing at the same time, a very high sensitivity to $\mathrm{NO}_{3}^{-}$ions (Admon et al. 1981, Walker and Leigh 1981, Churchill and Sze 1983, Bennett et al. 1984, Buczek and Sulej 1986). Both ATPases have a low sensitivity to azides and oligomycin (St out and Cleland 1982, O'Neill et al. 1983, Bennett et al. 1984, Buczek and Sulej 1986), in contrast to mitochondrial ATPase, which is inhibited both azides and oligomycin (Grubmeyer and Spencer 1980, Goffeau and Slayman 1981, Bennett et al. 1984).

The effect of other inhibitors on the activity of membrane-associated ATPases is little specific. DCCD - a non-specific inhibitor of plant membrane-associated ATPases (Schoner and Schmidt 1969, Solioz 1984) - inhibits the activity of the ATPases associated with the plasma membrane or tonoplast (O'Neill et al. 1983, Poole et al. 1984, Bennett et al. 1984, Buczek and Sulej 1986). Walker and Leigh (1981) and Buczek and Sulej (1986) have shown that the plasma membrane-associated ATPase was inhibited by the water-soluble carbodiimide (EDAC), while this inhibitor had no effect on the tonoplast ATPase. However, Lin et al. (1977), Bennet t and Spanswick (1983), O'Neill et al. (1983) and Poole et al. (1984) observed the inhibition of tonoplast ATPase by EDAC. Similarly, DES inhibited both the activity of the plasma membrane-associated ATP-ase (Bowman et al. 1979, Goffeau and Slayman 1981), and the tonoplast-associated ATPase (Aoki and Nishida 1984, Poole et al. 1984).

Earlier studies conducted in our laboratory (Buczek 1973) showed that sodium metavanadate inhibited the activity of nitrate reductase in tomato leaves. Orthovanadate acted simlarly in experiments on cucumber leaves and roots (Buczek, personal communication). It was also found (Buczek 1980) that vanadium and DCCD inhibited both the activity of nitrate reductase and the activity of ATPases in cucumber and maize roots and clearly reduced the uptake of $\mathrm{NO}_{3}^{-}$. It seems probable, then, that there is an interrelationship between the functioning of ATPases and the reduction of nitrates ( $\mathrm{Butz}$ and Jackson 1977), at least in respect to the active transport of $\mathrm{NO}_{3}^{-}$into cells.

Because of the above relationships, studies on the subcellular localization of $\mathrm{NO}_{3}^{-}$or $\mathrm{VO}_{4}^{3-}{ }^{-}$-sensitive ATPases and the effects of some ATPase and nitrate reductase inhibitors on the membrane-associated cucumber root ATPases were conducted in the first stage of this study.

\section{MATERIAL AND METHODS}

Plant material. The experiments were conducted on 6-day-old cucumber (Cucumis sativus L. var. Wisconsin) roots. Cucumber plants which had been germinated in the dark $\left(2\right.$ days at $\left.27^{\circ} \mathrm{C}\right)$, were grown for 3 days in a nitrogen-free medium of the following composition, in mM: $\mathrm{K}_{2} \mathrm{SO}_{4}-1 ; \mathrm{Ca}\left(\mathrm{H}_{2} \mathrm{PO}_{4}\right)_{2}$ 
- 0.33; $\mathrm{CaSO}_{4} \times 2 \mathrm{H}_{2} \mathrm{O}-0.7 ; \mathrm{MgSO}_{4} \times 7 \mathrm{H}_{2} \mathrm{O}-0.7$. Next, the plants were transferred to a medium with the following composition (mM): $\mathrm{KNO}_{3}-1.7$; $\mathrm{Ca}\left(\mathrm{NO}_{3}\right)_{2}-1.7 ; \mathrm{KH}_{2} \mathrm{PO}_{4}-0.33 ; \mathrm{MgSO}_{4} \times 7 \mathrm{H}_{2} \mathrm{O}-0.7$. Both mediums contained microelements in the following amounts $(\mu \mathrm{M})$ : iron citrate -75 , $\mathrm{MnSO}_{4}-10, \mathrm{CuSO}_{4} \times 5 \mathrm{H}_{2} \mathrm{O}-1, \mathrm{ZnSO}_{4} \times \mathrm{H}_{2} \mathrm{O}-0.01, \mathrm{NaMoO}_{4}-0.001$, and their $\mathrm{pH}$ equalled 6.5. The cucumbers were grown under a $16 \mathrm{~h}$ photoperiod $\left(10.3 \mathrm{~W} \mathrm{~m}^{-2}\right)$ and a daytime temperature of $25^{\circ} \mathrm{C}$, and nighttime temperature of $22^{\circ} \mathrm{C}$.

Isolation of membrane fractions. Approximately $50 \mathrm{~g}$ of 6-day-old cucumber roots were ground in a mortar with $200 \mathrm{~cm}^{3} 25 \mathrm{mM}$ Tris- $\mathrm{HCl}, \mathrm{pH} 7.5$, containing $250 \mathrm{mM}$ sucrose, $3 \mathrm{mM}$ EDTA, $4 \mathrm{mM}$ dithiothreitol and $0.1 \%$ bovine serum albumin (BSA). The homogenate was filtered through a double layer of Miracloth and centrifuged for $10 \mathrm{~min}$ at $13000 \times \mathrm{g}$. The sediment was discarded and the supernatant was centrifuged for $30 \mathrm{~min}$ at $80000 \times \mathrm{g}$. The pellet was suspended in $2 \mathrm{~cm}^{3}$ of extraction buffer and applied to either a linear or discontinuous sucrose density gradient. The linear gradient was formed in $16 \mathrm{~cm}^{3} 15-45 \%$ (w/w) sucrose. The discontinuous sucrose density gradient was made using $20 \%, 28 \%, 32 \%$ and $42 \%$ (w/w) sucrose solutions $\left(4 \mathrm{~cm}^{3}\right.$ of each). Sucrose was dissolved in $25 \mathrm{mM}$ Tris-MES, $\mathrm{pH} 7.5,3 \mathrm{mM}$ EDTA and $4 \mathrm{mM}$ dithiothreitol. The samples were centrifuged for $3 \mathrm{~h}$ at $80000 \times \mathrm{g}$. The fraction volume was $1.8 \mathrm{~cm}^{3}$. The entire procedure was carried out at $0-4^{\circ} \mathrm{C}$.

Assay of enzymic activity. ATPase activity was assayed in a reaction medium containing $33 \mathrm{mM}$ Tris-Mes (pH 7.5), $3 \mathrm{mM}$ ATP, $2.5 \mathrm{mM} \mathrm{MgSO}_{4}, 50 \mathrm{mM} \mathrm{KCl}$ and other substances, the type and amounts of which are given in the descriptions of the appropriate figures or tables. After 30 minutes of incubations at $37^{\circ} \mathrm{C}$, the reaction was stopped by adding trichloroacteic acid to a final concentration of $5 \%$. The activity of the ATPase was measured by the amount of phosphorous released during the enzymic reaction, as determined by the method of Ames (1966). The cytochrome oxidase activity was assayed according to Smith (1955), determining the rate of oxidation of reduced cytochrome c. The sucrose concentration in each fraction was determined refractometrically.

Abbreviations. $\mathrm{VO}_{4}$-ATPase - vanadium-sensitive ATPase, $\mathrm{NO}_{3}$-ATPase - nitrate-sensitive ATPase, $\mathrm{N}_{3}$-ATPase - azide-sensitive ATPase, DCCD - N-N'-dicyclohexylcarbodiimide, DES - diethylstibestrol, EDAC - 1ethyl-3-(3-dimethylaminopropyl) carbodiimide.

\section{RESULTS}

Figure 1 presents the separation of cell membranes (pellet obtained at $80000 \times \mathrm{g}$ ) from cucumber roots in a linear sucrose density gradient. The particular type of membrane was identified on the basis of the sensitivity of the various membrane-associated ATPases to inhibitors such as vanadium, nitra- 
tes and azides. The plasma membrane marker was the $\mathrm{VO}_{4}^{3-}$-sensitive ATPase, the ATPase inhibited by $\mathrm{NO}_{3}^{-}$was used as the tonoplast membrane marker and the ATPase sensitive to azides as the marker for mitochondrial membranes. It was shown that in all of the fractions obtained through centrifugation in a linear sucrose density gradient, there was only trace activity of cytochrome c oxidase, a marker of mitochondria, and that this was limited only to the first fraction with a specific density of $1.1816 \mathrm{~g} \times \mathrm{cm}^{-3}$ (Fig. 1b). Peak activity of the vanadium-sensitive ATPase was found in two fractions (3 and 4) with a specific density of 1.1463 and 1.1513. Slight activity of $\mathrm{N}_{3}$ -ATPase was also observed in these fractions. The highest activity of nitrate-sensitive ATPase was seen in fractions 5 and 6, having a specific density of 1.1082 and $1.1175 \mathrm{~g} \times \mathrm{cm}^{-3}$ (Fig. 1a).

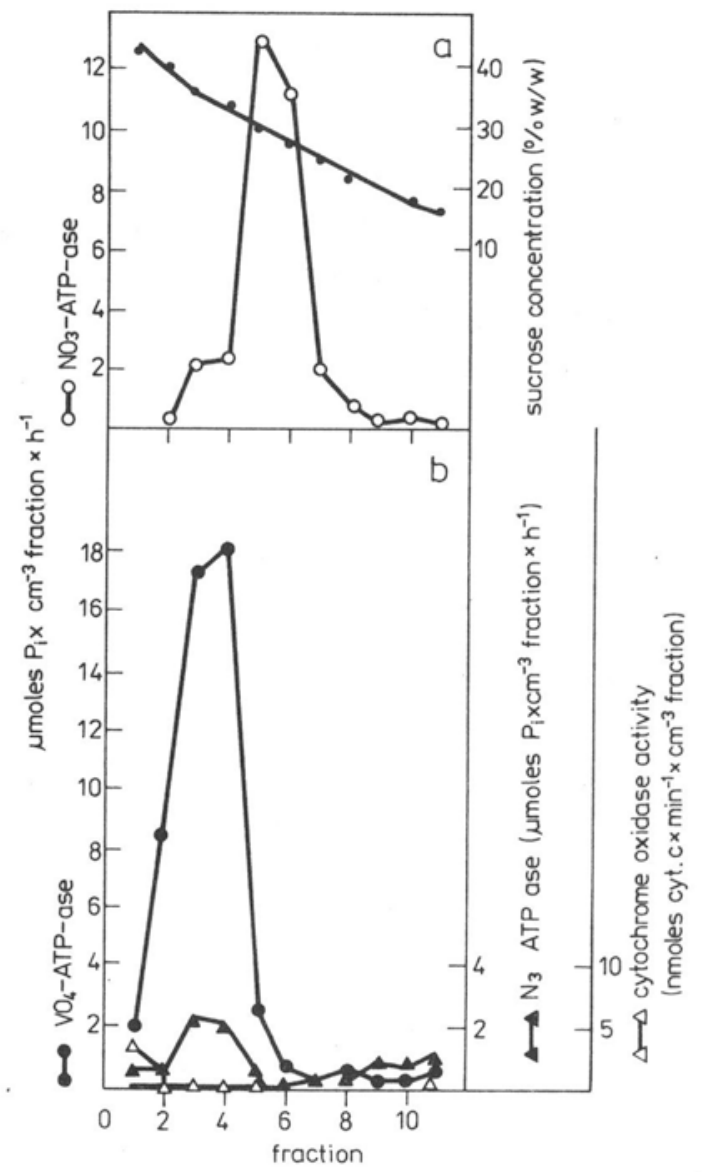

Fig. 1. The distribution of enzymic activity in fractions obtained by centrifugation of Cucumis sativus root cell membrane preparations in a linear sucrose density gradient. The activity of ATPases was assayed at pH 7.0. Control samples contained $33 \mathrm{mM}$ Tris-MES, 3mM ATP, 2.5 . $\mathrm{mM} \mathrm{MgSO}, 50 \mathrm{mM} \mathrm{KCl}, 1 \mathrm{mM} \mathrm{NaN}$. $50 \mu \mathrm{M} \mathrm{Na}{ }_{3} \mathrm{VO}_{4}$ and $50 \mathrm{mM} \mathrm{KNO}$. The activity of nitrate- sensitive ATPase ( $\mathrm{NO}_{3}$-ATPase) was assayed without $\mathrm{KNO}_{3}$, vanadium-sensitive ATPase

$\left(\mathrm{VO}_{4}\right.$-ATPase) without $\mathrm{Na}_{3} \mathrm{VO}_{4}$, and of the ATPase inhibited by azides, without $\mathrm{NaN}_{3}$ 
Centrifugation of microsomes obtained from cucumber roots in a discontinuous sucrose density gradient made it possible to obtain much better separation of the plasma membranes and tonoplast membranes (Fig. 2). Sharp and distinct separation of the peak activities of vanadium-sensitive and nitrate-sensitive ATPases was obtained. The activity of the $\mathrm{VO}_{4}$-ATPase was limited to fractions 3 and 4 , while the peak activity of $\mathrm{NO}_{3}$-ATPase (Fig. 2a) was not found until fractions 7 and 8 . There was only trace activity of cytochrome oxidase and this was limited to the first fraction. In fractions 1 and 4 a relatively low level of $\mathrm{N}_{3}$-ATPase was found (Fig. 2b).

Table 1 presents the sensitivity to various inhibitors of the ATPase in the plasma membrane-enriched fractions (specific density of $1.1463-1.1513 \mathrm{~g} \times \mathrm{cm}^{-3}$ ) or tonoplast-enriched fractions (specific density $1.1082-1.1175 \mathrm{~g} \times \mathrm{cm}^{-3}$ ). It was shown that the ATPases associated with high density membranes, strongly inhibited by vanadium, were not sensitive to nitrates, and that azides only

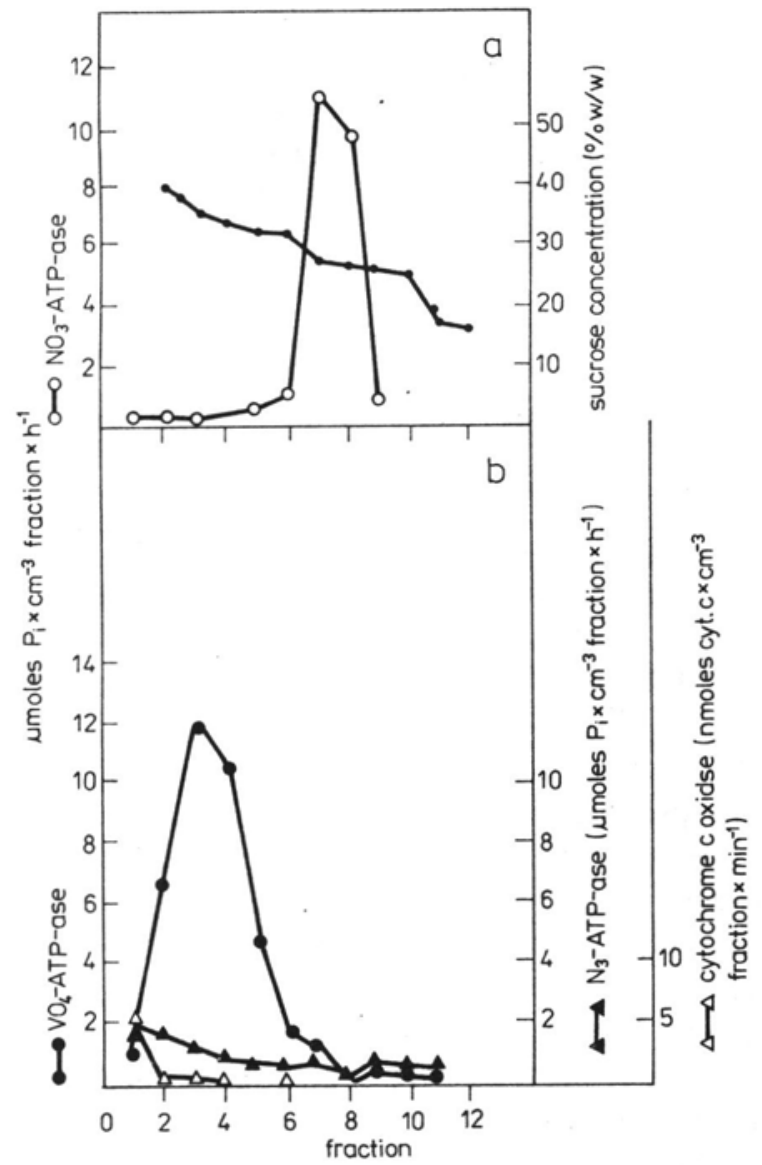

Fig. 2. The distribution of enzymic activity in fractions obtained by centrifugation of a preparation of cell membranes from Cucumis sativus roots in a step sucrose density gradient. Details as in Fig. 
slightly lowered their activity (by about $25 \%$ ). However, nitrates strongly inhibited the activity of ATPases in fractions with a low specific density. Vanadium and azide did not have this sort of effect on these ATPases. Both of these ATPases did not differ in their sensitivities to the remaining tested inhibitors. DCCD at a concentration of $20 \mu$ moles significantly lowered the activity of both $\mathrm{VO}_{4}$-ATPase and $\mathrm{NO}_{3}$-ATPase. Also DES at a concentration of $100 \mu$ moles clearly inhibited the activity of both ATPases. EDAC used at a concentration of $100 \mu$ moles did not change the activity of both enzymes. This occurred only when a 10 -fold greater concentration was used.

Table 1

The effect of inhibitors on the activity of $\mathrm{VO}_{4}$-ATPase and $\mathrm{NO}_{3}$-ATPase

\begin{tabular}{|l|c|c|}
\hline \multirow{2}{*}{\multicolumn{1}{c|}{$\begin{array}{c}\text { Inhibitor } \\
\text { (concentration) }\end{array}$}} & \multicolumn{2}{c|}{$\mu$ moles $\mathrm{P}_{\mathrm{i}} \times \mathrm{cm}^{-3}$} \\
\cline { 2 - 3 } & $\begin{array}{c}\mathrm{VO}_{4} \text {-ATPase } \\
\text { (fractions 3+4) }\end{array}$ & $\begin{array}{c}\mathrm{NO}_{3} \text {-ATPase } \\
\text { (fractions 7+8) }\end{array}$ \\
\hline $\mathrm{Control}^{*}$ & 35.56 & 24.77 \\
$\mathrm{NaN}_{3}(1 \mathrm{mM})$ & 30.10 & 23.98 \\
$\mathrm{Na}_{3} \mathrm{VO}_{4}(50 \mu \mathrm{M})$ & 5.83 & 23.02 \\
$\mathrm{KNO}_{3}(50 \mathrm{mM})$ & 34.81 & 4.52 \\
$\mathrm{DCCD}(20 \mu \mathrm{M})$ & 14.09 & 11.05 \\
$\mathrm{DES}(100 \mu \mathrm{M})$ & 11.43 & 9.11 \\
EDAC $(100 \mu \mathrm{M})$ & 37.06 & 24.06 \\
EDAC $(1 \mathrm{mM})$ & 26.29 & 13.77 \\
\hline
\end{tabular}

* Control samples contained $25 \mathrm{mM}$ Tris-MES pH 7.0. $3 \mathrm{mM} \mathrm{ATP.} 25 \mathrm{mM} \mathrm{MgSO}$ and $50 \mathrm{mM} \mathrm{KCl}$.

\section{DISCUSSION}

Centrifugation of a preparation of membranes from Cucumis sativus root cells in a sucrose density gradient enabled the separation of two different membrane fractions. The first, with a specific density of 1.1463-1.1513 $\mathrm{g} \times \mathrm{cm}^{-3}$, was characterized by high activity of $\mathrm{VO}_{4}$-inhibited ATPase. Both the specific density of the fractions and the presence of $\mathrm{VO}_{4}$-ATPase suggest that it was enriched in plasma membrane. Similar properties were exhibited by plasma membrane preparations isolated from soya (Lew and Spanswick 1984), beets (Poole et al. 1984) and Spirodella polyrrhiza (Buczek and Sulej 1986). The peak activity of $\mathrm{NO}_{3}$-ATPase, taken to be an enzyme specifically associated with tonoplast membranes (Admon et al. 1981, Leigh et al. 1979, Leigh and Walker 1980), was found in fractions with a specific density of 1.1175-1.1082, which is in agreement with preparations obtained from other plants (Bennett et al. 1984, DuPont et al. 1982). Since the $\mathrm{VO}_{4}$-ATPase did not change its activity when nitrates were added to the incubation medium, and the $\mathrm{NO}_{3}$-ATPase did not exhibit sensitivity to vanadium (Table 1), it can be accepted that the plasma membrane-enriched fractions obtained as the 
result of centrifugation of the $80000 \times \mathrm{g}$ pellet in a discontinuous sucrose density' gradient were free from tonoplast contaminants, and vice versa. The plasma membrane and tonoplast preparations were also free from contamination by mitochondrial membranes, which is indicated by the finding of only trace activities of cytochrome oxidase and $\mathrm{N}_{3}$-ATPase, or their total lack.

Inhibitors such as DCCD, DES and EDAC did not act specifically on only one membrane-associated cucumber root ATPase. DCCD and DES, thought to be by some authors (Leonard and Hodges 1973, Bowman et al. 1979, Goffeau and Slayman 1981) a specific inhibitor of membrane-associated ATPase, inibited in our experiments both the activity of $\mathrm{VO}_{4}$-ATPase and $\mathrm{NO}_{3}$-ATPase. Similar effects of these inhibitors on plasma membrane-associated or tonoplast-associated ATPases of beet cells were observed by Bennet t et al. (1984). Also EDAC, which selectively inhibited tonoplast ATPase while not affecting the activity of plasma membrane ATPase in membrane preparations from Spirodella polyrrhiza (Buczek and Sulej 1986), in our experiments slightly inhibited the activity of both enzymes.

Acknowledgement

This study was financed through CPBP 5.02.

\section{REFERENCES}

Admon A., Jacoby B., Goldschmidt E., 1981. Some characteristics of the Mg-ATPase of isolated red beet vacuoles. Plant Sci. Lett. 22: 87-96.

Ames B. N., 1966. Assay of inorganic phosphate, total phosphate and phosphatases. Methods Enzymol. 8: 115-118.

Aoki K., Nishida K., 1984. ATPase activity associated with vacuoles and tonoplast vesicles isolated from CAM plant, Kolanchoë daigremontiana. Physiol. Plant. 60: 21-25.

Bennett A. B., O'Neill S. D., Spanswick R. M., 1984. H $^{+}$-ATPase activity from storage tissue of Beta vulgaris. I. Identification and characterization of an anion-sensitive $\mathrm{H}^{+}$-ATPase. Plant Physiol. 74: 538-544.

Bennett A. B., Spanswick R. M., 1983. Solubilization and reconstitution of an anion-sensitive $\mathrm{H}^{+}$-ATPase from corn roots. J. Membrane Biol. 75: 21-31.

Bowman B. J., Mainzer S. E., Allen K. E., Slavman C. W., 1979. Effects of inhibitors on plasma membrane fraction of oat roots by diethylstilbestrol. Plant Physiol. 63: 48-52.

Buczek J., 1973. Effects of vanadium on nitrate reductase activity in tomato leaves. Acta Soc. Bot. Pol. 42: 223-232.

Buczek J., 1980. Reduction of nitrates in Cucumis sativus L. seedlings. II. Influence of tungsten and vanadium on nitrate reductase and adenosine triphosphatase activities. Acta Soc. Bot. Pol. 49: 269-280.

Buczek J., Sulej J., 1986. Density gradient localization of vanadate-and $\mathrm{NO}^{-}$-sensitive ATPase from sterile cultures of Spirodela polyrrhiza (L.) Schleiden. Acta Soc. Bot. Pol. 55: 253-262.

Butz R. G., Jackson W. A., 1977. A mechanism for nitrate transport and reduction. Phytochemistry 16: 409-417.

Churchill K. E., Sze H., 1983. Anion sensitive $\mathrm{H}^{+}$-pumpkin ATPase in membrane vesicles from oat roots. Plant Physiol. 71: 610-617. 
DuPont F. M., Bennett A. B., Spanswick R. M., 1982. Localization of a proton-translocating ATPase on sucrose gradients. Plant Physiol. 70: 1115-1119.

Gallagher S. R., Leonard R. T., 1982. Effect of vanadate, molybdate and azide on membrane-associated ATPase and soluble phosphatase activities of corn roots. Plant Physiol. 70: 1335-1340.

Goffeau A., Slayman C. W., 1981. The proton-translocating ATPase of the fungal plasma membrane. Biochim. Biophys. Acta 639: 197-223.

Grubmeyer C., Spencer M., 1980. ATPase activity of pea cotyledon submitochondrial particles. Activation, substrate specifity, and anion effects. Plant Physiol. 65: 281-285.

Leigh R. A., Rees T. A. P., Fuller W. A., Banfield J., 1979. The location of acid invertase activity and sucrose in the vacuoles of storage roots of beetroot (Beta vulgaris). Biochem. $\mathrm{J}$. 178: 539-547.

Leigh R. A., Walker R. R., 1980. ATPase and acid phosphatase activities associated with vacuoles isolated from storage roots of red beet (Beta vulgaris L.). Planta 150: 222-229.

Leonard R. T., Hodges T. K., 1973. Characterization of plasma membrane-associated adenosine triphosphatase activity of oat roots. Plant Physiol. 52: 6-12.

Lew R. R., Spanswick R. M., 1984. Proton pumping activities of soybean (Glycine max L.) root microsomes: localization and sensitivity to nitrate and vanade. Plant Sci. Lett. 36: 187-193.

Lin W., Wagner G. J., Siegelman H. W., Hind G., 1977. Membrane-bound ATPase of intact vacuoles and tonoplasts isolated from mature plant tissue. Biochim. Biophys. Acta 465: 110-117.

O'Neill S. D., Bennett A. B., Spanswick R. M., 1983. Characterization of a $\mathrm{NO}_{3}$ -sensitive $\mathrm{H}^{+}$-ATPase from corn roots. Plant Physiol. 72: 837-846.

Poole R. J., Briskin D. P., Kratky Z., Johnstone R. M., 1984. Density gradient localization of plasma membrane and tonoplast from storage tissue of growing and dormant red beet. Characterization of proton-transport and ATPase in tonoplast vesicles. Plant Physiol. 74: 549-556.

Schoner W., Schmidt Hm. 1969. Inhibition of $\left(\mathrm{Na}^{+}+\mathrm{K}^{+}\right)$-activated ATPase by N,-N'dicyclohexylcarbodiimide. FEBS Lett. 5: 285-287.

Smith L., 1955. Methods in enzymology. Colowick S. P., Kaplan N. O. (eds.) vol. 2, Academic Press, New York. pp. 740.

Solioz M., 1984. Dicyclohexylcarbodiimide as a probe for proton translocating enzymes. Trends Biochem. Sci. 9: 309-312.

Stout R. G., Cleland R. E., 1982. Evidence for a $\mathrm{Cl}^{-}$-stimulated $\mathrm{MgATPase}$ proton pump in oat root membranes. Plant Physiol. 69: 798-803.

Sze H., 1984. $\mathrm{H}^{+}$-translocating ATPases of the plasma membrane and tonoplast of plant cells. Physiol. Plant. 61: 683-691.

Walker R. R., Leigh R. A., 1981. Characterization of a salt-stimulated ATPase activity associated with vacuoles isolated from storage roots of red beet (Beta vulgaris). Planta 153: 140-149.

\section{Lokalizacja wrażliwych na wanad $i$ azotany ATPaz $w$ komórkach korzeni} Cucumis sativus $L$.

\section{Streszczenie}

W wyniku wirowania frakcji mikrosomalnej komórek korzeni ogórka w gradiencie gęstości sacharozy użyskano wyraźne rozdzielenie błon plazmalemmy i tonoplastu. Frakcje wzbogacone w plazmalemmę, identyfikowane na podstawie wrażliwości $\mathrm{ATPaz}$ na $\mathrm{VO}_{4}^{3-}$. osiadały przy 
gęstości właściwej 1,1463-1,1513 $\mathrm{g} \times \mathrm{cm}^{-3}$. Nie wykazywały aktywności oksydazy cytochromowej, a aktywność ATPazy wrażliwej na działanie azydku była w tych frakcjach jedynie śladowa. Frakcje wzbogacone w tonoplast, wykazujące maksymalną aktywność ATPazy hamowanej przez azotany, znajdowano w obszarze gęstości właściwej 1,1082-1,1175 $\mathrm{g} \times \mathrm{cm}^{-3}$. W tych frakcjach nie stwierdzono obecności ATPaz wrażliwych na wanad ani ATPaz hamowanych przez azydek. Inhibitory ATPaz (DCCD, DES i EDAC) hamowały aktywność ATPaz wrażliwych na wanad oraz ATPaz wrażliwych na azotany. 